\title{
The Vertical File: Retain or Discard?
}

\section{Evelyn Payson}

Should academic libraries maintain vertical files in an era of increased competition for scarce library resources? This study discusses the costs and benefits of vertical files and analyzes the results of a survey sent to 171 academic libraries at four-year, nondoctoral campuses in six midwestern states in the summer of 1993. Vertical file practices at the 139 responding libraries varied greatly. The libraries with no vertical files and those with large and active files were significantly more satisfied with their current policies than other libraries with infrequently maintained files.

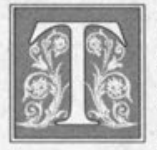

o have, or not to have a vertical file: that is the question. Is a public access vertical file collection worth having? If a library chooses to have one, how much care and attention does it merit, and what sort of care and attention? How does one balance the costs and benefits of the file? In a technological and computerized era, does it still make sense to have a vertical file?

This article examines both the benefits and the burdens of possessing and maintaining a vertical file. While the article does not offer definitive recommendations about having a vertical file, it does conclude that if a library is to be satisfied with its vertical file, it must allocate sufficient staff time and material resources to maintain it well. This paper surveys what has been written about vertical files over the past fifteen to twenty years and presents the results of a survey conducted by the University of WisconsinWhitewater on current vertical file practices in libraries and their perceived success.

\section{Literature Survey and Background}

For the past several decades, academic librarians have devoted little time to asking or answering the fundamental questions about having a vertical file. ${ }^{1}$ Most authors are firmly committed to maintaining the traditional vertical file and have extolled its virtues without seriously questioning its existence.

Vertical files tend to become little-used backwaters of librarianship, tucked away in quiet corners, peaceably aging and decaying. Still true today is Josephine Schneider's statement of 1951 that "often librarians give this part of the collection very little thought, sometimes because of lack of time, but more often because they are not interested in such material and they fail to see the values of it." ${ }^{2} \mathrm{Com}$ ments in response to the survey such as "The vertical file is the lowest priority on my job description as Public Services Librarian," and "No one on my staff has cared enough in many years to work with the V.F. collections" indicate that vertical files are definitely not a top priority for many librarians. 


\section{Importance of Vertical File Materials}

Despite the lack of interest in vertical files, some librarians have recognized the importance of pamphlets and related materials. Mimi Gronlund summarized the benefits of pamphlets thus:

Pamphlets offer unique and important advantages. They can provide information on current subjects before that information is available in books ... Pamphlets offer a concise presentation of information that may be more appropriate for the library patron than a book. ${ }^{3}$

Shirley Miller thought the advantages were so great that "For your investment of time and money, you will get a return great enough to turn a Wall Street speculator green with envy." 4

With the volume of pamphlets and other grey material ever growing and the amount of available staff time ever shrinking, the question of whether to maintain a vertical file becomes increasingly important. As Barbara Allen points out:

Ours is truly an information age... Much of this information is published in looseleaf, pamphlet, booklet or newsletter format-items libraries traditionally do not add to their permanent collections. Yet such information sources are not just ephemeral in nature; they contain data not found elsewhere in the library, which make vital contributions to academic research and must therefore be made available to patrons. ${ }^{5}$

Several authors have commented on the value of nonconventional material for current information. Susan Lovenburg and Frederick Stoss state: "Few sources are as good when one wishes to understand all the sides of a controversial issue." ${ }^{6}$ Marc Levin declares, "Often literature issued by policy research organiza- tions is the only source of independent information that objectively evaluates important policy questions." ${ }^{\text {7 }}$ Peter Allison remarks that vertical file material "digests and summarizes knowledge for busy decision makers."

Several of the respondents to the current survey echoed these views. One wrote, "The file is exceedingly useful for contemporary topics and topics of interest to this college, e.g., women's issues, justice issues. It is particularly useful for keeping information about these topics which are not often or well reported in standard information sources."

\section{Lack of Academic Esteem}

Despite the value of the information it contains, even a well-maintained and accessible vertical file may not be heavily used. Many faculty tend to regard refereed journal articles or university press books as more acceptable sources for student papers than policy papers or technical reports. In 1981 Tom Hodgson and Andrew Garoogian described the "basic indifference" to pamphlets which were "seen as lacking in 'scholarly virtue'."

Librarians themselves tend to shun the vertical file and see vertical file work as professionally counterproductive. Julie Still stated that "Librarians are reluctant to take on responsibility for the VF because it is not perceived as a steppingstone to success," possibly because "the vertical file is perceived as a low-tech tool in a high-tech world." ${ }^{10,11}$ Respondents to the survey reported here supported her view with comments like "Students attracted to bells and whistles of technology view vertical files as outdated," or "Our students do not tend to like to use the vertical file because it does not have the appeal that computers do."

\section{Processing Problems}

Another reason libraries do not make more use of grey literature is that major problems arise in handling it. These problems have existed for decades, but they 
grow more acute as librarians wrestle with dividing ever more scarce resources among a constantly increasing range of programs.

Finding sources for material can be difficult. Standard publications such as the Vertical File Index list only a portion of the useful pamphlets. Scanning journals and newspapers to find references to potentially valuable material is time-consuming and laborious. Providing balanced points of view in vertical files is difficult or impossible. Often vertical file material is created by groups that take strong positions and consequently produce biased publications. For instance, during the 1970s and 1980s the South African government produced much of the readily available material on apartheid. ${ }^{12}$

Acquiring and processing vertical file material is difficult. Ordering units at many libraries are reluctant to process small orders and require hard-to-obtain detailed bibliographic citations. Few catalogers want to handle vertical file materials. Cataloging problems arise frequently, and cataloging copy is often not available. Most items are as brief as journal articles, making it difficult to justify the time needed for cataloging. Consequently, catalogers often view vertical file items as low priority and relegate them to backlog shelves for years or even decades.

\section{Access to Vertical File Material}

If vertical file material is not cataloged, alternate means of making it accessible must be employed. The most common means of providing access to a vertical file collection is, and has been, a file of subject cards. However, maintaining one is time-consuming and patrons often do not or cannot use it to find the information they seek. As one of the surveyed librarians wrote, "There are treasures to be found, but access is not good."

Some libraries have tried other ways of making material accessible. Joy Thomas at California State University Library, Long Beach, reported success with preparing printed lists of pamphlet file subject headings. ${ }^{13}$ The Alexandria campus of Northern Virginia Community College reported success with integrating pamphlets into the collection by placing them in suitably labelled Princeton files in the proper location on the shelves. ${ }^{14}$

Adding pamphlet subject headings to the online catalog has proven successful at a number of libraries, including the University of Utah Health Sciences Center Library. ${ }^{15}$ Several of the surveyed libraries have begun this practice. One of them wrote of the "great improvement in access achieved by creating one online OPAC record for each folder (subject)." When the University of WisconsinWhitewater created NOTIS online catalog records for pamphlet folder headings, vertical file use more than tripled, as table 1 indicates.

The 139 respondents to the current study indicated that they made pamphlet material accessible in a variety of ways. Most of the thirty-seven libraries without vertical files cataloged a few important pamphlets and discarded the rest. Of the 102 with vertical files, most provided subject heading access, either through a separate file or by incorporating them into a

TABLE 1

UW-Whitewater Vertical File Circulation Statistics (Broad Subject Headings Entered Online, 1992-93)

\begin{tabular}{rcccc}
\hline \hline $1989 / 90$ & $1990 / 91$ & $1991 / 92$ & $1992 / 93$ & $1993 / 94$ \\
\hline 2,191 & 1,899 & 1,768 & 3,508 & 5,989 \\
\hline
\end{tabular}


main catalog. A few libraries provided no external finding aids. Two of the surveyed libraries provided users with listings of the actual items in the vertical files, one in paper format, one online. Both felt these efforts were useful.

\section{Keeping Vertical Files Current}

After vertical files have been created, they lose value rapidly unless they are weeded. Thomas declares, "Unless a vigorous, consistent weeding policy is pursued, it [the vertical file] can quickly become clogged with out-of-date material.

\section{Pamphlets stating that someday mankind may land on the moon or discussing sexually transmit- ted diseases without mentioning AIDS do not belong in the vertical file....}

This discourages students who seek information on a current development and assume that a preponderance of old pamphlets signifies the absence of new data." 16 Pamphlets stating that someday mankind may land on the moon or discussing sexually transmitted diseases without mentioning AIDS do not belong in the vertical file unless they are being kept for their historical value.

\section{Literature Summary}

Judging from the literature, the answer to the question of whether a vertical file is truly worthwhile is no clearer than it was in 1981 when Hodgson and Garoogian stated that "an ambivalent feeling still persists among academic librarians towards the value of pamphlet collections in college libraries."17 Although many librarians regard the material as valuable, it is difficult to handle and make accessible, and doubts about its merit persist.

\section{Survey}

In the summer of 1993, the author prepared a questionnaire and sent it to the 171 academic libraries with 60,000 or more volumes at four-year, nondoctoral campuses in Illinois, Indiana, Iowa, Michigan, Minnesota, and Wisconsin. The goal of the survey was to learn how libraries were actually handling vertical files and how satisfied they were with their current practices. Of the 171 libraries surveyed, 139 replied, for a response rate of 81 percent. Thirty-two of the 139 were at public institutions and 107 at private. Two libraries had two distinct vertical files and submitted responses for both; each response was treated as a separate vertical file. Two of the 139 responding libraries indicated that they were in the process of changing procedures and could not complete the questionnaire. Approximately three-fourths (102 of 139 or $73.4 \%$ ) of the responding libraries had a vertical file, while $37(26.6 \%)$ did not.

\section{Libraries without Vertical Files}

Libraries which do not have vertical files are confronted with the problem of what

\section{TABLE 2}

Libraries without Vertical Files:

Satisfaction with Handling of Pamphlets and Similar Materials

\begin{tabular}{lcc}
\hline \hline & Number $(\mathrm{N}=33)$ & Percent \\
\hline 1. Very Satisfied & 13 & 39.4 \\
2. Moderately Satisfied & 9 & 27.3 \\
3. Neutral & 6 & 18.2 \\
4. Not Very Satisfied & 2 & 6.1 \\
5. Not at All Satisfied & 3 & 9.1 \\
\hline
\end{tabular}


to do with pamphlets and ephemera. Most material is discarded or not collected, although over half of the libraries responding ( 21 of 37 , or $57 \%$ ) indicated that they did catalog some pamphlets or ephemera. Survey comments included, "If it is worth having, it's worth cataloging," "Catalog or discard," and "Catalog (or don't collect if not substantial)."

Most of the libraries without vertical files are satisfied with their present practices, as table 2 indicates. On a 1 to 5 scale of satisfaction with their handling of materials that might be included in a vertical file, the average score was 2.18.

Three-fourths of the libraries ( 27 of 36 responding) had once had a vertical file but decided to discontinue it, while the others had never started one. Twenty-five $(69 \%)$ of the libraries were not interested in starting or reinstituting a vertical file. When given a list of reasons for not having vertical files, 32 of the 37 responding libraries $(86 \%)$ said a vertical file was too time-consuming; 25 (68\%) believed it wouldn't be used enough; $19(51 \%)$ thought the information was readily available elsewhere; and 16 (43\%) didn't think they had the resources to start and maintain one.

Comments from several libraries reflected their opinion that not having a vertical file was a wise decision. One respondent wrote that the staff "found low use relative to the effort needed to collect, categorize and maintain." Another described the vertical file as "not cost effective," and a third provided three reasons for not having a vertical file: "(1) too labor intensive, (2) can be rip[ped] off too easily, [and] (3) outdated idea."

Other libraries would welcome a vertical file if it proved feasible. "I am not happy with the status quo, but am at a loss on how to proceed without unduly tying up staff and resources," wrote one
TABLE 3

Vertical File Size

Libraries (N=91) \% of Libraries

14.3

13.2

14.3

23.1

22.0

13.2

library director. Another librarian commented that "A vertical file would be a nice thing if we could really keep it upthere's just not enough time. And now staff time is deluged with new technologies-CD-ROMs, online searching, etc. Too much new to learn-no time for old technologies that may have been useful."

\section{Libraries with Vertical Files}

Libraries with vertical files reported widely diverse situations and policies. Some libraries had small, single-purpose files such as corporate annual report collections. Other libraries had large and actively maintained files, while still others kept previously established vertical files without maintaining them.

Libraries with vertical files indicated less satisfaction with their current practices than those without. However, the libraries with the largest vertical file collections or the highest number of additions were approximately as satisfied as those without vertical files.

\section{Size and Activity of Vertical Files}

The sizes of the vertical files at the reporting libraries varied enormously. The smallest contained only a few hundred items, the largest 54,000 . The distribution shown in table 3 appears to be roughly logarithmic.

While most libraries gave vertical file size in terms of items, several used file folders or drawers as their units. For purposes of the survey, one file folder was 
TABLE 4

Annual Vertical File Additions

\begin{tabular}{ccc}
\hline \hline Number Added & Libraries $(\mathrm{N}=86)$ & \% of Libraries \\
\hline $0-50$ & 18 & 20.9 \\
$51-100$ & 20 & 23.3 \\
$101-250$ & 18 & 20.9 \\
$251-500$ & 13 & 15.1 \\
$>500$ & 17 & 19.8 \\
\hline
\end{tabular}

types of material, as table 5 shows. The most commonly used formal selection tools were the Vertical File Index, the government's Consumer Information Catalog, and the Educator's Guide to Free Materials. No selection tools were used at 29.4 percent of the libraries assumed to contain ten items; one file cabinet drawer 250 .

Like the number of items in the vertical file, the number of items added per year varied widely. Again, as shown in table 4, the distribution appears to be approximately logarithmic.

Withdrawal data were contradictory and difficult to interpret. Most libraries ( 83 of 98 or $84.7 \%$ ) reported that they kept material for fewer than ten years, but the actual withdrawal figures were far too small to support their claims. Only 37 percent of the responding libraries withdraw more than 100 items a year. The discrepancy may result from the difference between ideal and actual practices or from the tendency to weed on a multiyear cycle.

\section{Type of Material in Vertical Files}

Most vertical files contained a variety of with vertical files ( 30 of 102 ); 21.6 percent (22 of 102) used more than one selection tool.

Acquiring vertical file materials that were not free was difficult for many libraries. Fewer than half (46 of 102) of the libraries with vertical files $(45.1 \%)$ reported purchasing any vertical file material, and only six $(5.9 \%)$ purchased more than ten percent of the items they added. One surveyed librarian commented, "If something is not free, we don't bother with it." Over 85 percent of libraries ( 87 of 102 with vertical files) did not report having any formal vertical file budget. A few libraries commented that they could pay at least some of the postage costs involved in acquiring free items but could not purchase vertical file material. Similar findings appear in the literature. Allen noted that "many managers of information files have to operate on zero bud-

TABLE 5

Types of Material Collected in Vertical Files

\begin{tabular}{lcc}
\hline \hline Type of Material & Number Collecting $(\mathrm{N}=99)$ & Percent Collecting \\
\hline Pamphlets & 94 & 94.9 \\
Maps & 76 & 76.8 \\
Travel/Tourist Material & 76 & 76.8 \\
U.S. Govt. Documents & 64 & 64.6 \\
Newspaper Clippings & 60 & 60.6 \\
Periodical Articles & 57 & 57.6 \\
Other Govt. Documents & 50 & 50.5 \\
Technical Reports & 37 & 37.4 \\
Pictures/Photographs & 36 & 36.4 \\
Other: Corp. Annual Repts. & 19 & 19.2 \\
Other: Misc. & 30 & 30.3 \\
\hline
\end{tabular}


gets." ${ }^{18}$ Juleigh Clark found that 31 of 33 responding libraries in South Carolina did not have vertical file budgets, although eight were able to purchase material from the book or supply budget. ${ }^{19}$

\section{Personnel}

Professionals do most of the vertical file work at the surveyed libraries, with a majority of responding libraries ( 25 of 41) spending 25 or fewer hours per year on selecting materials. Processing material demanded considerably more time than selecting it, but over two-thirds of the libraries (30 out of 42) used 50 or fewer hours each year. Withdrawing materials consumed less time than either selecting or adding. Almost half (20 out of 41$)$ of the libraries spent ten or fewer hours a year.

At almost all the libraries the total time spent on the vertical file was less than three hours a week. The time expended seems to have diminished since 1980 when Hodgson and Garoogian found most City University of New York (CUNY) colleges using three to ten hours per week. ${ }^{20}$

\section{Vertical File Use}

Librarians tend to think that their patrons did not make extensive use of vertical file material. When asked how heavily their vertical files were used (on a 1 to 5 scale: $1=$ very, $5=$ not at all) the average response was 3.15 .

Thirty-two of the 74 libraries which provided annual circulation figures reported circulating 50 or fewer items, 15 circulated 51-100, 11 circulated 101-200, nine circulated 201-1,000, and seven circulated from 1,001 to 8,000 .

Libraries with large or actively maintained collections were significantly more likely to think that their collections were heavily used than those with small or static collections. The Pearson correlation coefficient between size and perceived use was .4678 , between number added and perceived use .4268 , and between number withdrawn and perceived use .3822. All three are significant at a less than .01 confidence level. Table 6 illustrates the relationship between annual acquisitions and perceived use.

When asked "How useful do you think patrons find vertical file material?" librarians felt it was somewhat useful. The average estimate of usefulness was 2.73 on a five-point scale ranging from 1 (very) to 5 (not at all). These figures can be compared with those reported from a survey of vertical file users at the University of Evansville, where 13 of the 31 respon-

\section{TABLE 6}

Yearly Additions and Estimated Use of Vertical File ( $N=86$ )

\begin{tabular}{lcccccc}
\hline \hline Yearly Additions & \multicolumn{4}{c}{$\begin{array}{c}\text { How heavily do you feel VF is used? } \\
\text { (No. of responses) }\end{array}$} & Mean Use \\
\hline & $\begin{array}{c}1 \\
\text { Very }\end{array}$ & $\begin{array}{c}2 \\
\text { Moderately }\end{array}$ & $\begin{array}{c}\text { Somewhat } \\
\text { Sot Very }\end{array}$ & $\begin{array}{c}\text { Not At All } \\
\text { Not }\end{array}$ & Avg. Use \\
\hline $0-50$ & & 3 & 6 & 7 & 3 & 3.53 \\
$51-100$ & & 3 & 6 & 11 & & 3.40 \\
$101-250$ & 1 & 2 & 9 & 7 & & 3.15 \\
$251-500$ & & 3 & 7 & 3 & & 3.00 \\
$>500$ & 4 & 5 & 4 & 2 & & 2.27
\end{tabular}

(In addition to the cases shown above, 3 libraries did not reply to the question on estimated use, and 13 others did not give annual acquisitions figures. Two of the 13 felt the vertical file was moderately heavily used, 4 felt it was somewhat used, and 7 felt it was not very heavily used.) 
TABLE 7

Collection Size and Estimated User Satisfaction

\begin{tabular}{lcccccc}
\hline \hline Vertical File Size & \multicolumn{4}{c}{ How useful do you feel patrons find VF? } & Mean Usefulness \\
\hline & $\begin{array}{c}1 \\
\text { Very }\end{array}$ & $\begin{array}{c}2 \\
\text { Moderately }\end{array}$ & $\begin{array}{c}3 \\
\text { Somewhat }\end{array}$ & $\begin{array}{c}4 \\
\text { Not Very }\end{array}$ & $\begin{array}{c}5 \\
\text { Not At All }\end{array}$ & Avg. Use \\
\hline $1-500$ & & 1 & 5 & 6 & 1 & 3.54 \\
$501-1,000$ & 2 & 1 & 9 & & & 2.58 \\
$1,001-2,000$ & 1 & 2 & 8 & 3 & & 2.92 \\
$2,001-5,000$ & 2 & 3 & 11 & 3 & & 2.78 \\
$5,001-10,000$ & 2 & 8 & 10 & 1 & & 2.47 \\
10,001 up & 3 & 5 & 4 & & & 2.08 \\
\hline
\end{tabular}

(Nine libraries which responded to the usefulness question did not report collection size. One of the nine felt the vertical file was very useful, two felt it was moderately useful, four felt it was somewhat useful, and two felt it was not very useful.)

dents felt that the vertical file had been very helpful, 16 that it had been somewhat helpful, and two that it had not been helpful. $^{21}$

Again, librarians with larger or more active vertical files tended to respond more positively than those with small or inactive files. Table 7 presents the statistics for collection size; a similar pattern emerges for the number of items added annually. The Pearson correlation coefficients were significant at the less than .01 level for correlation between collection size and perceived value (.4019) and between yearly additions and perceived value (.4001). The correlation between withdrawals and perceived value (.2783) was significant at the less than .05 level.

The questionnaire asked the respondents to choose the three most valuable

\section{TABLE 8}

\section{Does the Usefulness of the VF Justify Its Cost?}

\begin{tabular}{lcc}
\hline \hline & Libraries (N=101) & Percent \\
\hline Definitely (1) & 19 & 18.8 \\
Probably (2) & 35 & 34.6 \\
Neutral (3) & 30 & 29.7 \\
Probably Not (4) & 12 & 11.9 \\
Not at All (5) & 5 & 4.9 \\
\hline
\end{tabular}

types of vertical file materials. The first choice was pamphlets for beginning-level papers, followed in order by travel and tourist information, historical material and clippings, pamphlets used for more advanced papers, technical reports, and corporate annual reports.

\section{Satisfaction with Vertical Files}

Two questions assessed how satisfied librarians were with their vertical files. The first asked whether the respondents believed that the vertical file was useful enough to justify its cost in time and money, and the second asked whether the responding librarians were satisfied with their institutions' current vertical file policies.

A majority of the librarians with vertical files believed that the usefulness of the vertical file definitely or probably justified its cost in time and money, as table 8 indicates. The average rating was 2.50 on a 1 to 5 scale $(1=$ definitely, $5=$ not at all).

Once again, the larger the vertical file collection, the more satisfied librarians appeared. Table 9 
shows the correlation which was statistically significant at the $<.01$ level (.2771). As might be expected, the belief that having a vertical file was justified was strongly correlated with the degree to which the librarians felt it was used $(<.01$ level, $.4490)$, and with how useful librarians thought users found it (<.01 level, .4921).

Librarians with large or active vertical files were also most likely to be satisfied with the current vertical file policies at their institutions, and again the correlation was statistically significant at the $<.01$ level. The average level of satisfaction with the policies was 2.55 on a five-point scale. At libraries adding over 500 items a year, it was 1.94; at libraries adding fewer than 50 items, it was 3.06 . The correlation of satisfaction with both collection size (.3087) and number of items added annually (.3534) was statistically significant at the <.01 level.

\section{And for the Future?}

A substantial number of librarians (37.1\%, 36 of 97 responding) reported that they were considering changes in their vertical file policies and procedures in the future. Sixteen of these were contemplating eliminating their vertical files, and eight were considering expanding them.

When asked to select areas of concern, a majority of the responding librarians

TABLE 10

Vertical File Concerns (N=99)

\begin{tabular}{lcc}
\hline \hline Area of Concern & Libraries (N=99) & $\%$ of Libraries \\
\hline Personnel Time & 52 & 52.5 \\
Materials Cost & 21 & 21.2 \\
Accessibility & 43 & 43.4 \\
Extent of Use & 68 & 68.7 \\
Other & 16 & 16.2 \\
\hline
\end{tabular}

\section{TABLE 9}

Belief that Vertical File Is Justified

( $1=$ Definitely, $5=$ Not at All)

\begin{tabular}{lcc}
\hline \hline VF Collection Size & Libraries $(\mathrm{N}=92)$ & Mean Response \\
\hline $1-500$ & 13 & 3.08 \\
$501-1,000$ & 12 & 2.58 \\
$1,001-2,000$ & 14 & 2.57 \\
$2,001-5,000$ & 20 & 2.30 \\
$5,001-10,000$ & 21 & 2.33 \\
10,001 and up & 12 & 2.00 \\
\hline
\end{tabular}

indicated concern about the extent of vertical file use $(68.7 \%)$ and the amount of personnel time that vertical file operations demand $(52.5 \%)$. Almost half (43.4\%) were concerned about making vertical file information easily locatable and accessible. Table 10 indicates the areas of concern.

\section{Conclusions}

The merits of the adage that "A thing worth doing is worth doing well" are demonstrated by the survey results. Those libraries that decide not to have a vertical file and those libraries that decide to have large and active vertical files are both significantly more satisfied with their situations than the libraries that have small or infrequently maintained vertical files.

Conversely, when libraries do not spend the time necessary to build, maintain, and provide access to their vertical files, they are unlikely to be satisfied with it. As one of the surveyed librarians remarked, "It consumes a lot of time and needs much support and encouragement to be successful." The survey results seem to indicate that libraries which are unwilling or unable to commit the necessary resources might be more satisfied if they discontinued their vertical files.

Providing online catalog access to information about 
the contents of the vertical file holds promise for increasing vertical file use.

\section{Libraries with large or actively maintained collections were significantly more likely to think that their collections were heavily used than those with small or static collections.}

While there were not enough cases where vertical file headings were added to an online catalog to draw statistically significant conclusions, it appears to work well for the libraries using it.

No clear answer exists to the question of whether it is worth having a vertical file in the first place, provided that the vertical file is adequately maintained. On the one hand, those libraries which choose not to have a vertical file forego access to significant amounts of valuable material, much of which is not readily available except in pamphlet form. On the other hand, they save significant amounts of personnel time which can be used to provide other library services. Whether the access to additional information justifies the cost in time and money of having a well-maintained vertical file is a question for each library to weigh, considering its own situation and recognizing that halfway measures are unlikely to prove satisfactory.

\section{Notes}

1. Much of what has been written since the nineteenth century is reprinted in Michael D. G. Spencer, ed., Readings on the Vertical File (Littleton, Colo.: Libraries Unlimited, 1993).

2. Tom Hodgson and Andrew Garoogian, "A Special Collection in College Libraries: The Vertical File," Reference Services Review 9 (July 1981): 77.

3. Mimi Gronlund, "Pamphlets-A Question of Format," Unabashed Librarian 42 (1982): 9.

4. Shirley Miller, "Pamphlets and Clippings," in Readings on the Vertical File, 3. Originally published in Shirley Miller, The Vertical File and Its Satellites, 2d ed. (Littleton, Colo.: Libraries Unlimited, 1979).

5. Barbara F. H. Allen, "The Information File in Academic Libraries: An Unexploited Resource," Collection Management 16, no. 3 (1992): 53-54.

6. Susan L. Lovenburg and Frederick W. Stoss, "The Fugitive Literature of Acid Rain: Making Use of Nonconventional Information Sources in a Vertical File," Reference Services Review 16, no.1-2 (1988): 95-96

7. Ibid., 31

8. Peter Allison, "Stalking the Elusive Grey Literature," College \& Research Libraries News 5 (May 1987): 244-45.

9. Hodgson and Garoogian, "A Special Collection," 77. 37.

10. Julie Still, "The Vertical File in Academic Libraries," Show-Me Libraries 39 (spring 1988):

11. Ibid., 37.

12. David Lane, "Your Pamphlet File Supports Apartheid," Library Journal 115 (Sept. 1, 1990): 174-77.

13. Joy Thomas, "Rejuvenating the Pamphlet File in an Academic Library," Library Journal 110 (Oct. 15, 1985): 43-45.

14. Gronlund, "Pamphlets-A Question of Format," 9.

15. Maureen O. Carleton and Catherine G. Cheves, "The Vertical File Enters the Electronic Age," in Readings on the Vertical File, 81-89. Originally published in Medical Reference Services Quarterly 8, no. 4 (winter 1989): 1-10.

16. Thomas, "Rejuvenating the Pamphlet File," 43.

17. Hodgson and Garoogian, "Special Collections," 77.

18. Allen, "The Information File," 57.

19. Juleigh Clark, "The Vertical File in South Carolina Academic Libraries," in Readings on the Vertical File, 104-08. Originally published in South Carolina Librarian 31 (spring 1987): 34-36.

20. Hodgson and Garoogian, "A Special Collection," 21.

21. R. L. Abbott, "Vertical Files Still Standing Tall," Unabashed Librarian 72 (1989): 25-27. 